\title{
BACK TO THE FUTURE - ANDRIJA MOHOROVIČIĆ LECTURE (1909) \& ZAGREB (2020) M5.5 EARTHQUAKE
}

\author{
Davor Stanko $^{1 *}$, Snježana Markušićc ${ }^{2} \&$ Davorin Penava ${ }^{3}$ \\ ${ }^{1}$ University of Zagreb, Faculty of Geotechnical Engineering, Hallerova aleja 7, HR-42000, Varaždin \\ ${ }^{2}$ University of Zagreb, Faculty of Science, Geophysical Department, Horvatovac 95A, HR-10000, Zagreb \\ ${ }^{3}$ Josip Juraj Strossmayer University of Osijek, Faculty of Civil Engineering and Architecture Osijek, Vladimir \\ Prelog 3, HR-31000, Osijek \\ *E-mail of corresponding author: davor.stanko@gfv.unizg.hr
}

\begin{abstract}
This review paper relates original Mohorovičić, A. lecture DJELOVANJE POTRESA NA ZGRADE (1909, 1911) and its English translation EARTHQUAKE EFFECTS ON BUILDINGS (2009) with M5.5 Zagreb 2020 earthquake damage. Mohorovičic said in Introduction of his lecture in 1909: "another strong earthquake is needed to remind people that the building techniques should be further developed and improved...”. Oliver Wendell Holmes (1809-1894) said once: "The young man knows the rules, but the old man knows the exceptions". This should remined us that going Back to the Future after strong earthquake, we must go Back to the Past, and look after Mohorovičić's 15 rules how to build earthquake-resistant buildings. He tells us how to build, and unfortunately, we were left unprepared again and didn't listen wisdom words of an "old man". Keywords: Andrija Mohorovičić lecture, Zagreb 2020 earthquake, Djelovanje potresa na zgrade, Earthquake effects on buildings.
\end{abstract}

Received: 05.05.2020. / Accepted: 03.06.2020.

Published online: 10.07.2020.

Review paper

https://doi.org/10.37023/ee.7.1.1

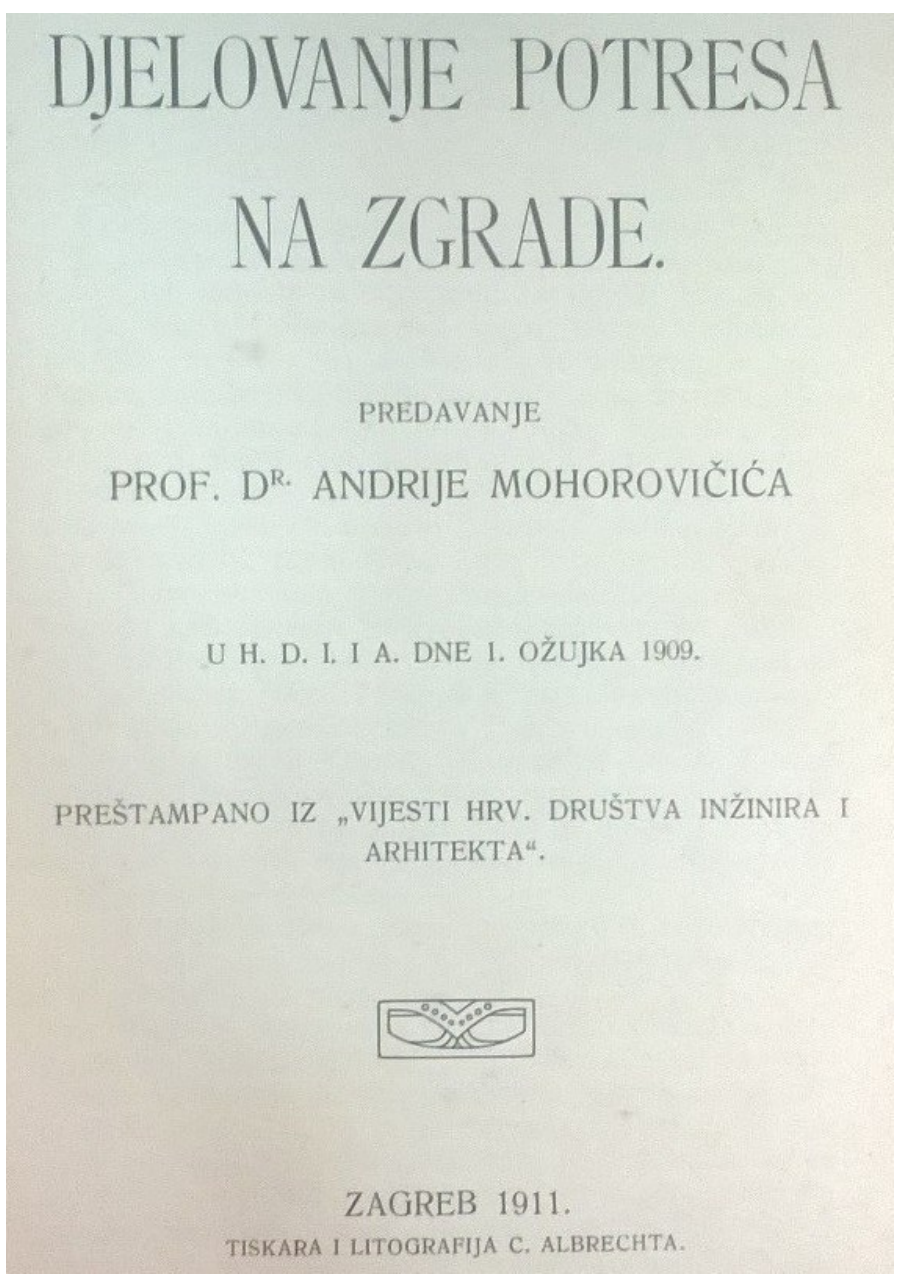

Figure 1. Effects of earthquakes on buildings. Lecture given by Professor Andrija Mohorovičić, Ph. D. at the Croatian Society of Engineers and Architects (CSEA) on March 1st, 1909 


\section{BACK TO THE PAST - WHAT WAS ANDRIJA MOHOROVIČIĆ TELLING US...}

"... Systematic study of earthquakes has also one very practical aspect. Strong earthquakes often cause great damage to houses and other buildings, and occasionally they level to the ground large and rich cities and bury thousands of people under the ruins. Therefore, one of the most important goals of seismology is to theoretically study how the movement of the earth affects buildings, and to apply these results as well as the experience gained in catastrophic earthquakes to show the ways of constructing buildings resistant as much as possible against earthquakes...." (Mohorovičić 1913, 2009; Herak \& Herak 2009).

"...In order to study earthquake effects on buildings, we must first accurately represent the shaking of soil beneath the building, as well as the forces the shaking exerts, and then we must study how these forces affect the building as a whole and its individual parts...” (Herak \& Herak 2007)

"...I take this opportunity to warn all responsible institutions of outdated building codes, which completely disregard the ways earthquakes affect buildings. In March of this year (1909) I have delivered a lecture on that subject in the Society of Engineers and Architects in Zagreb, and I stressed the need to consider earthquakes when buildings are constructed, I will soon publish the extended edition of the lecture (Figure 1, 2). So far, my appeals fell on deaf ears; after the lecture, many buildings were erected in Zagreb that pose threat for passers-by, as well as to themselves...." (Mohorovičić 1909, 1911, 2009; Herak \& Herak 2009).

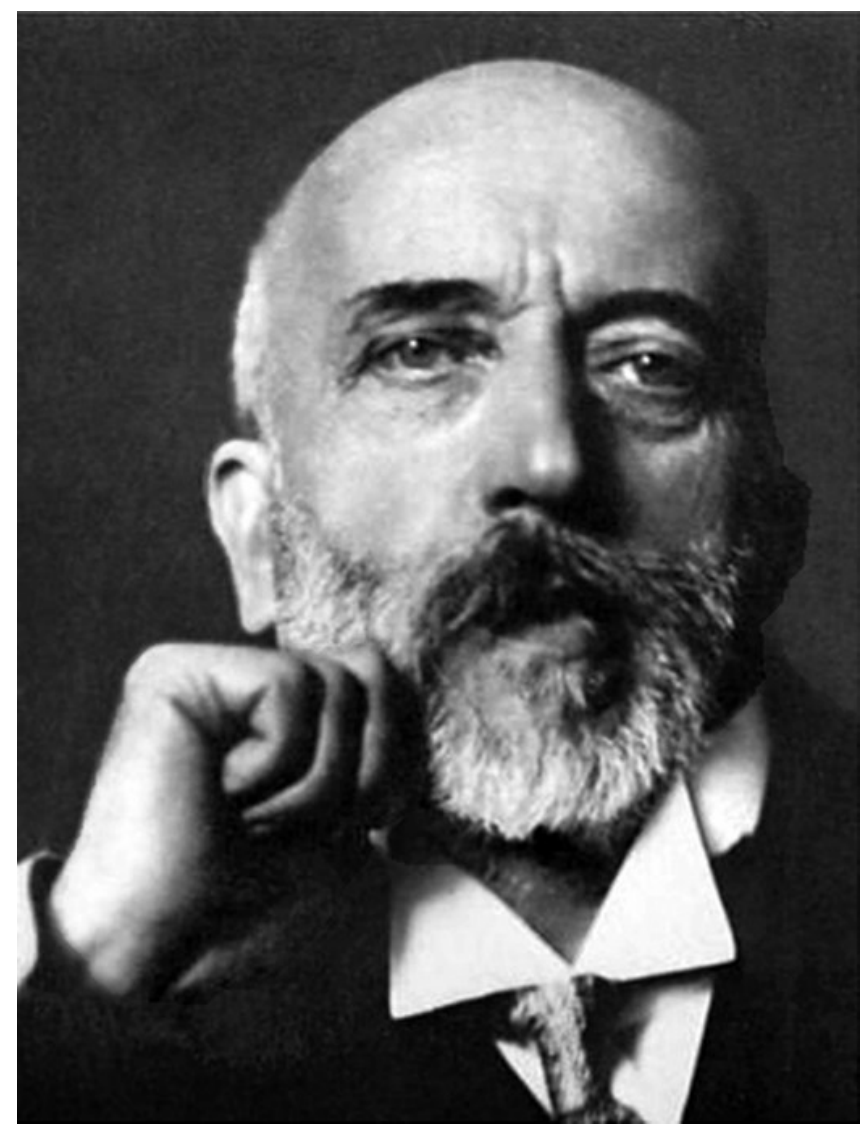

Figure 2. Dr. Andrija Mohorovičić (1857-1936), geophysicist of the world renown and one of the greatest Croatian scientists of all times

\section{BACK TO THE FUTURE - 22 MARCH 2020 ZAGREB EARTHQUAKE}

“...After each major earthquake, in the engineering circles one discusses the damage which affected the buildings during the catastrophe, and possible means of prevention against the damage. From these discussions, many ideas usually emerge on alterations which should be introduced into the traditional building ways. But such is the human nature that, as soon as the first fears are over the feeling of security prevails, and nobody considers any further changes; moreover, even those which have been accepted immediately after an earthquake get forgotten. Another strong earthquake is needed to remind people that the building techniques should be further developed and improved..." (Mohorovičić 1909, 1911, 2009).

At approximately 6:24 CET on the Sunday morning of 22 March 2020, a 5.5 magnitude earthquake struck Zagreb, Croatia, with an epicenter $7 \mathrm{~km}$ north of Zagreb city centre. The maximum felt intensity was VII (Very strong) on the Modified Mercalli intensity scale (Figure 3), or VII-VIII ${ }^{\circ}$ MCS (Mercalli-Cancani-Sieberg) scale. 
It was felt all over Croatia, even at distances of more than $1000 \mathrm{~km}$ from the epicenter. After about 15 seconds of intense shaking, nothing will be in Zagreb as it was before. People did not even manage to be prepared, the vast majority were just preparing to leave their homes when another powerful earthquake occurred at 7 hours and 1 minute. This time of magnitude 5.0 according to Richter. The third strong shaking was recorded at 7 hours and 41 minutes, earthquake with magnitude 3.7 according to Richter. In just over 24 hours since the main shock, 57 earthquakes with magnitudes greater than or equal to 2.0 happened in Zagreb (Markušić et al. 2020).

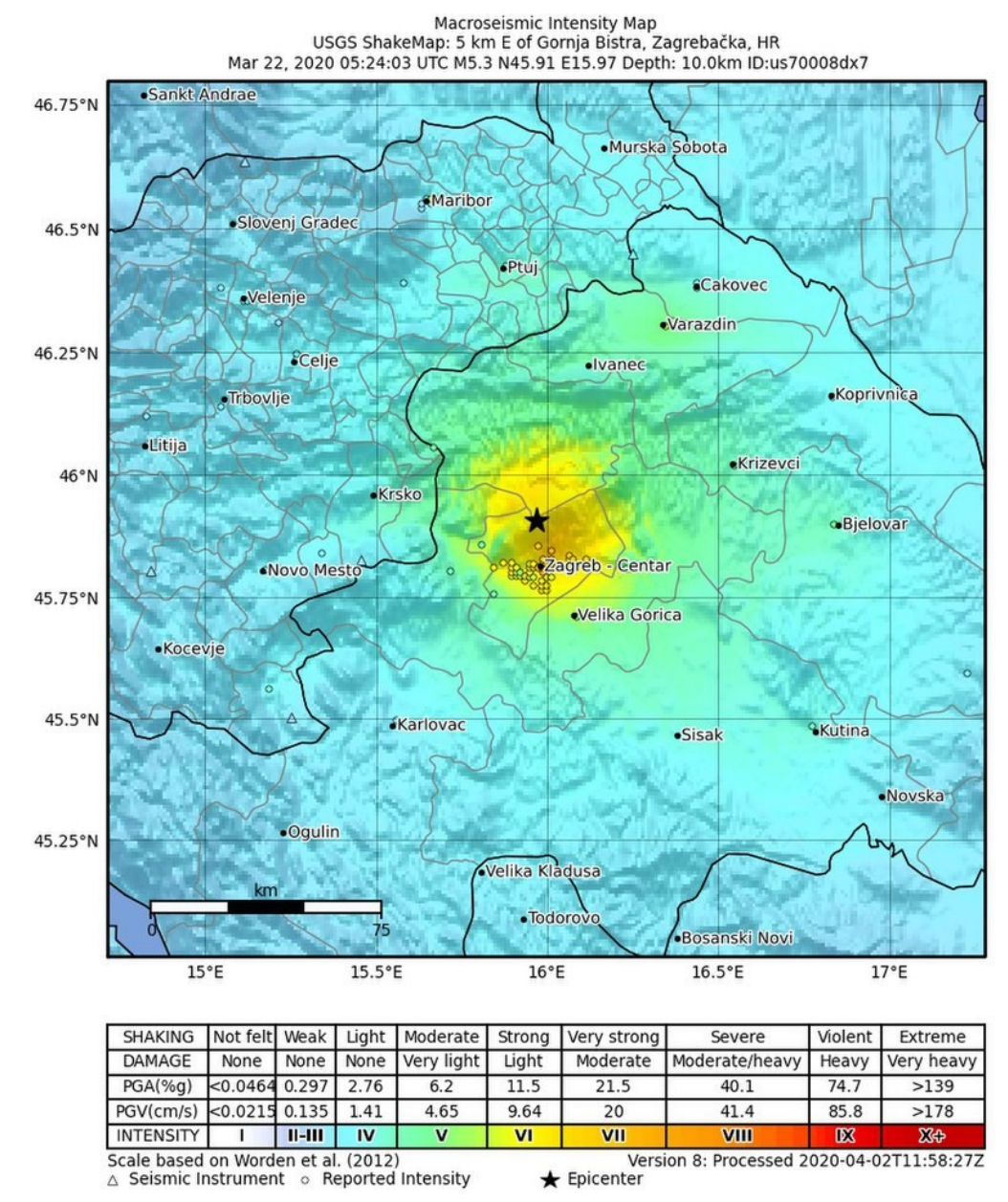

Figure 3. Macroseismic intensity map of the 2020 main earthquake in Zagreb, Croatia. https://earthquake.usgs.gov/earthquakes/eventpage/us $70008 \mathrm{dx} 7 /$ shakemap/intensity

The main shock was the strongest earthquake in Zagreb since the "Great Zagreb 1880 earthquake" and caused substantial damage in the historical city center. All were stunned with the damage of the top of the Cathedral's south tower (Figure 4). A numerous damage to the cultural and historical architectural heritage of the City of Zagreb have been reported (Figure 5). Many churches were heavily damaged (Figures 6 \& 7 ) as well as the Croatian Parliament building. Most of the museums and theatres in the city's centre suffered also serious damage (e.g., the Museum of Arts and Crafts, the Croatian History Museum, the Schools Museum, Komedija Theatre, the Croatian National Theatre). Over 1,900 buildings (up to now) are reported to have become uninhabitable by the earthquake damage, particularly buildings built before 1964. In places around the epicenter, the situation was very bad because of the destroyed houses (Figure 8) (Markušić et al. 2020).

The earthquake occurred during the 2020 coronavirus pandemic. It must be stressed out that this was lucky coincidence for citizens of Zagreb due to coronavirus lockdown restrictions and Sunday morning earthquake event when people were still sleeping, resulting in only 27 injured people and, unfortunately, one teenage girl died from her injuries.

Croatian government and Zagreb city administration presented plans and new law for the renovation of the damaged structures, but as Mohorovičić $(1909,1911,2009)$ said "...such is the human nature that, as soon as the first fears are over the feeling of security prevails, and nobody considers any further changes; moreover, even those which have been accepted immediately after an earthquake get forgotten...", we must stress out importance that we all (people, government, engineers, scientists) need to learn from this M5.5 earthquake "mistakes" and closely work together for the future events. The damage occurred to various kinds of buildings is shown in Figures. 4 to 8. More figures about earthquake damage in Zagreb can be seen in the Appendix. 


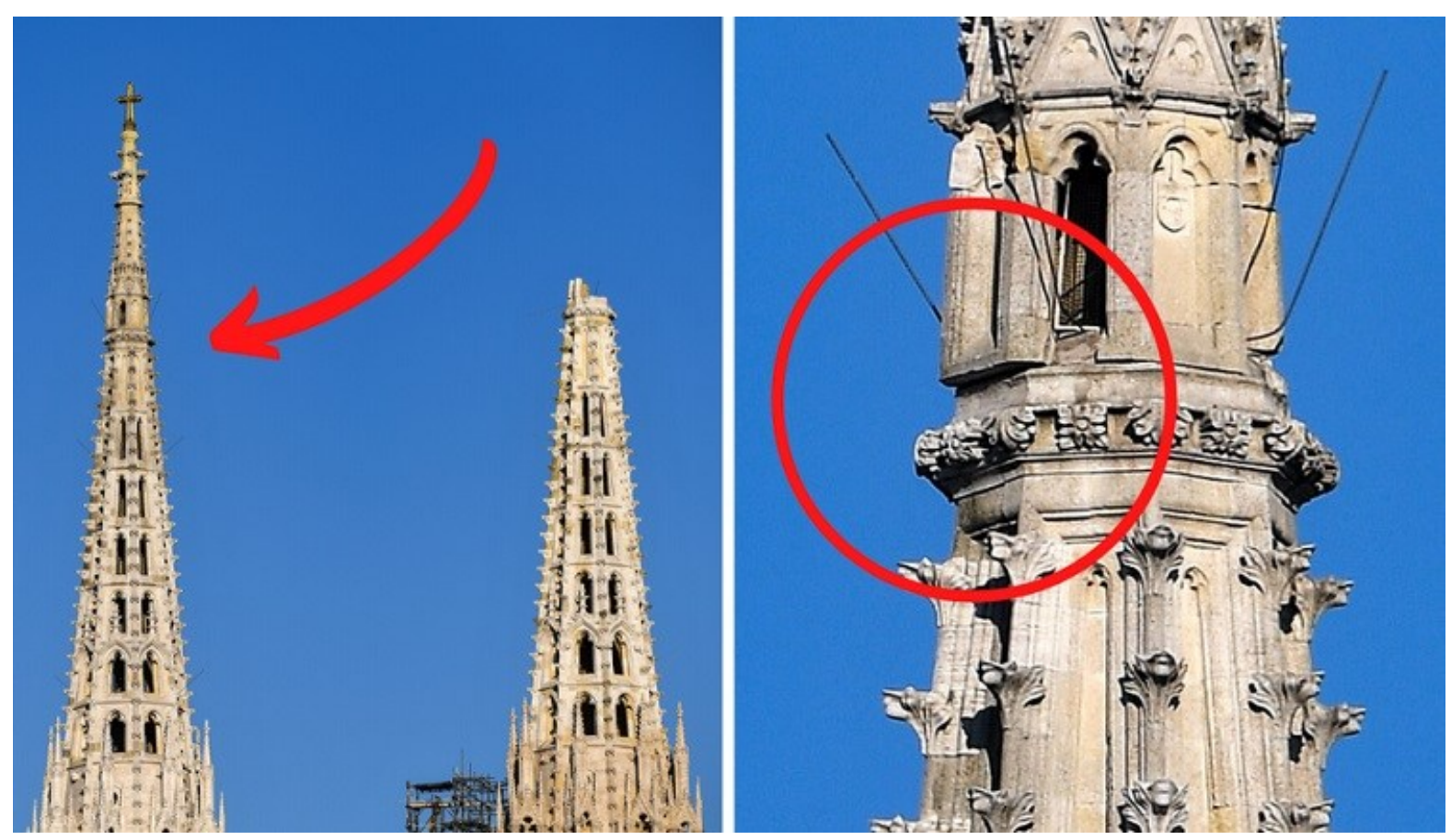

Figure 4. Damage of the top of the Cathedral's south tower. North tower was removed to limit further damage from aftershocks on 17 April 2020.

https://www.24sata.hr/news/pogledajte-kako-se-pomaknuo-toranj-za-cak-12-centimetara-684927/galerija-624839 https://www.poslovni.hr/hrvatska/foto-danas-se-sigurno-krece-u-rusenje-tornja-katedrale-4226919

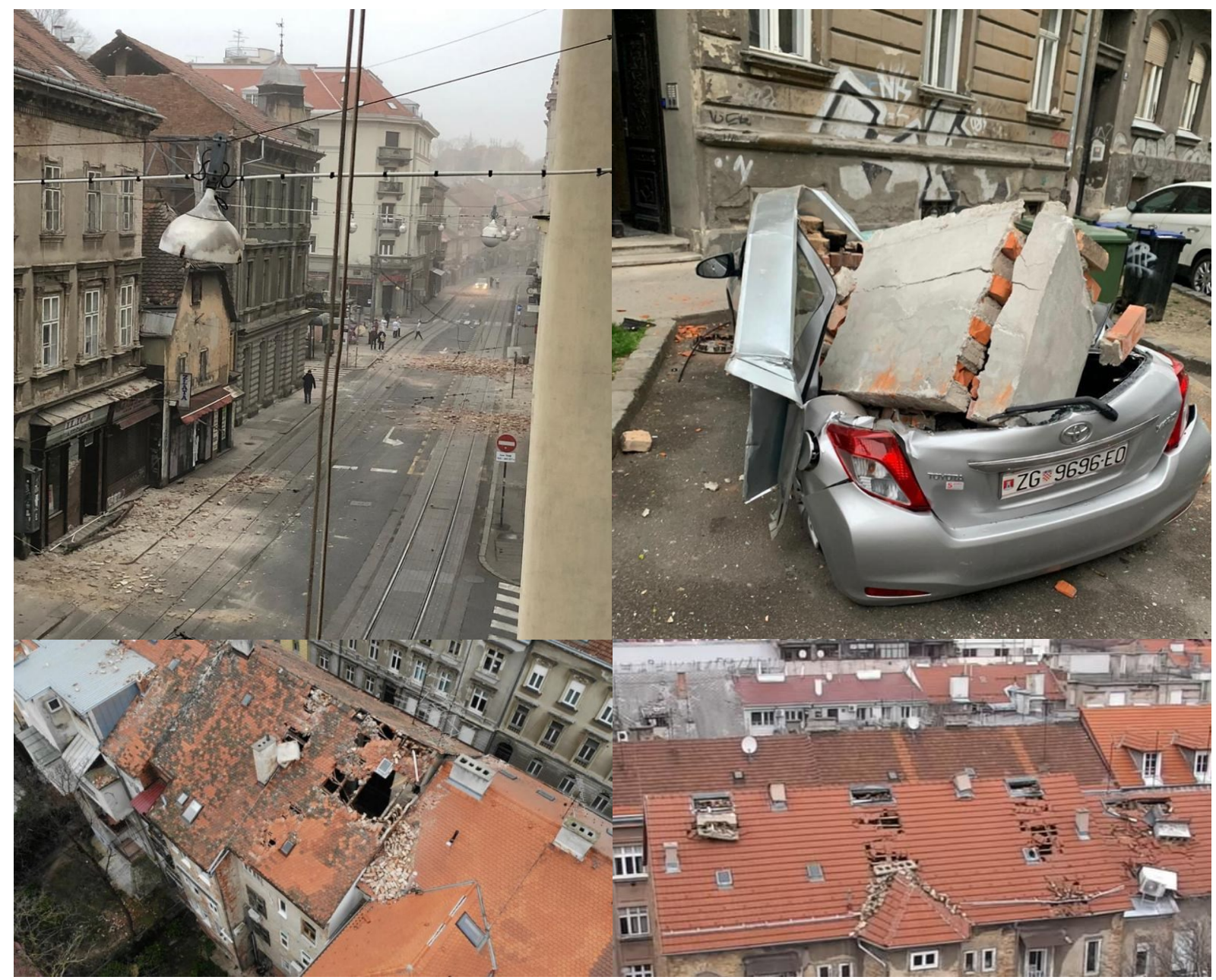

Figure 5. Damage in Zagreb after 22 March M5.5 earthquake. Noticeable roof tile loss and chimney collapse https://narod.hr/hrvatskalfoto-video-pogledajte-fotografije-nakon-potresa-u-zagrebu-srusio-se-vrh-katedrale 


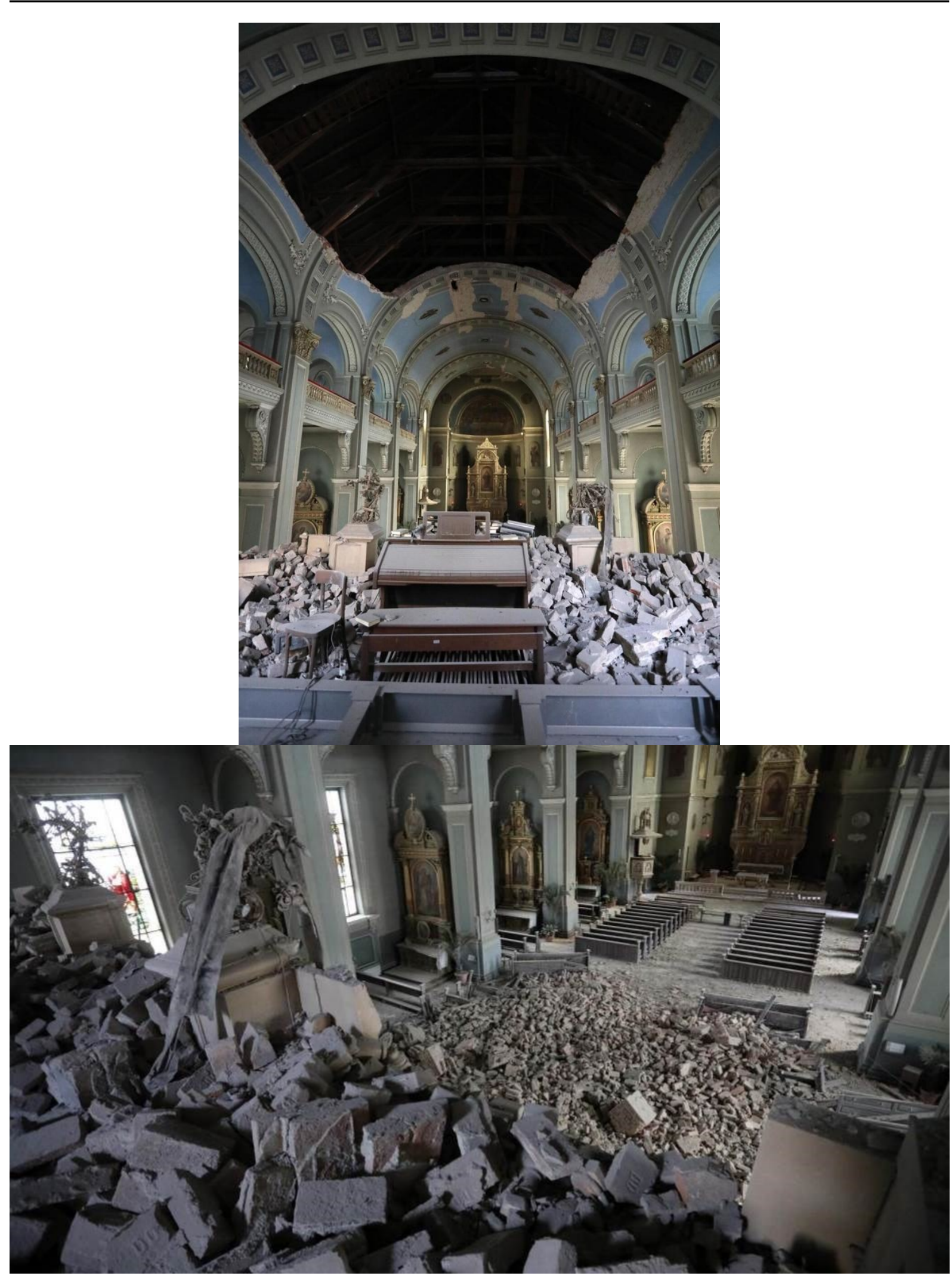

Figure 6. Damage to cultural heritage: Basilica of the Heart of Jesus from 1902 https://www.24sata.hr/news/crkva-u-palmoticevoj-unistena-urusio-se-strop-iznad-ulaza-682556

The problem of building performance, as observed in Figures 4 to 8, lies partially in inadequate design with respect to corresponding seismic demand, and in other part in lack of implementation, or lack in general, of available research solutions for their protection (e.g. the heritage building Shrine of Saint Mary of Remete dating from 1786 shown in Figure 7 was already once severely damaged in 1880 Zagreb earthquake). For the seismic safety purposes, it is therefore required to adopt and enforce the seismic rules and regulations (e.g. see Table 1), with particular attention to cultural heritage sites. 


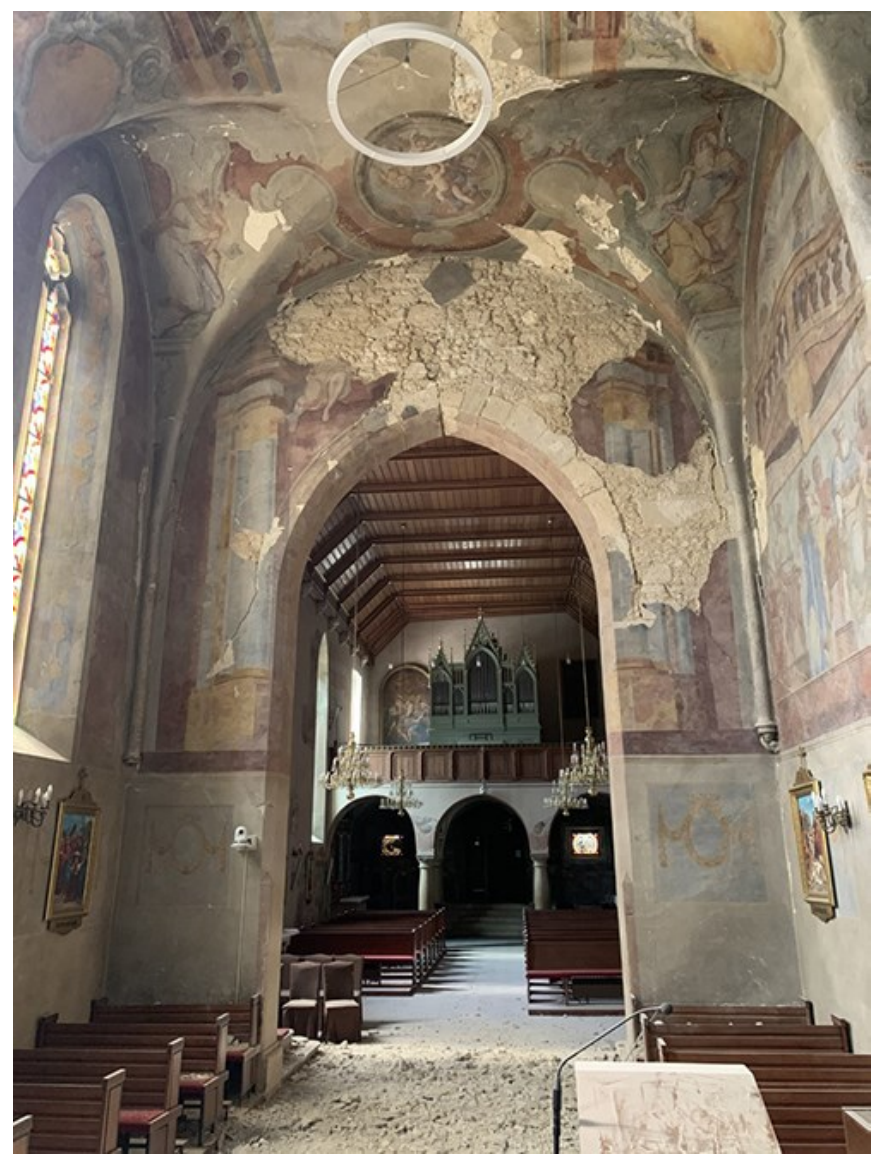

Figure 7. Damage to cultural heritage: Shrine of Saint Mary of Remete from 1786 https://www.24sata.hr/news/pogledajte-trenutak-potresa-u-crkvi-u-remetama-u-zagrebu-682565

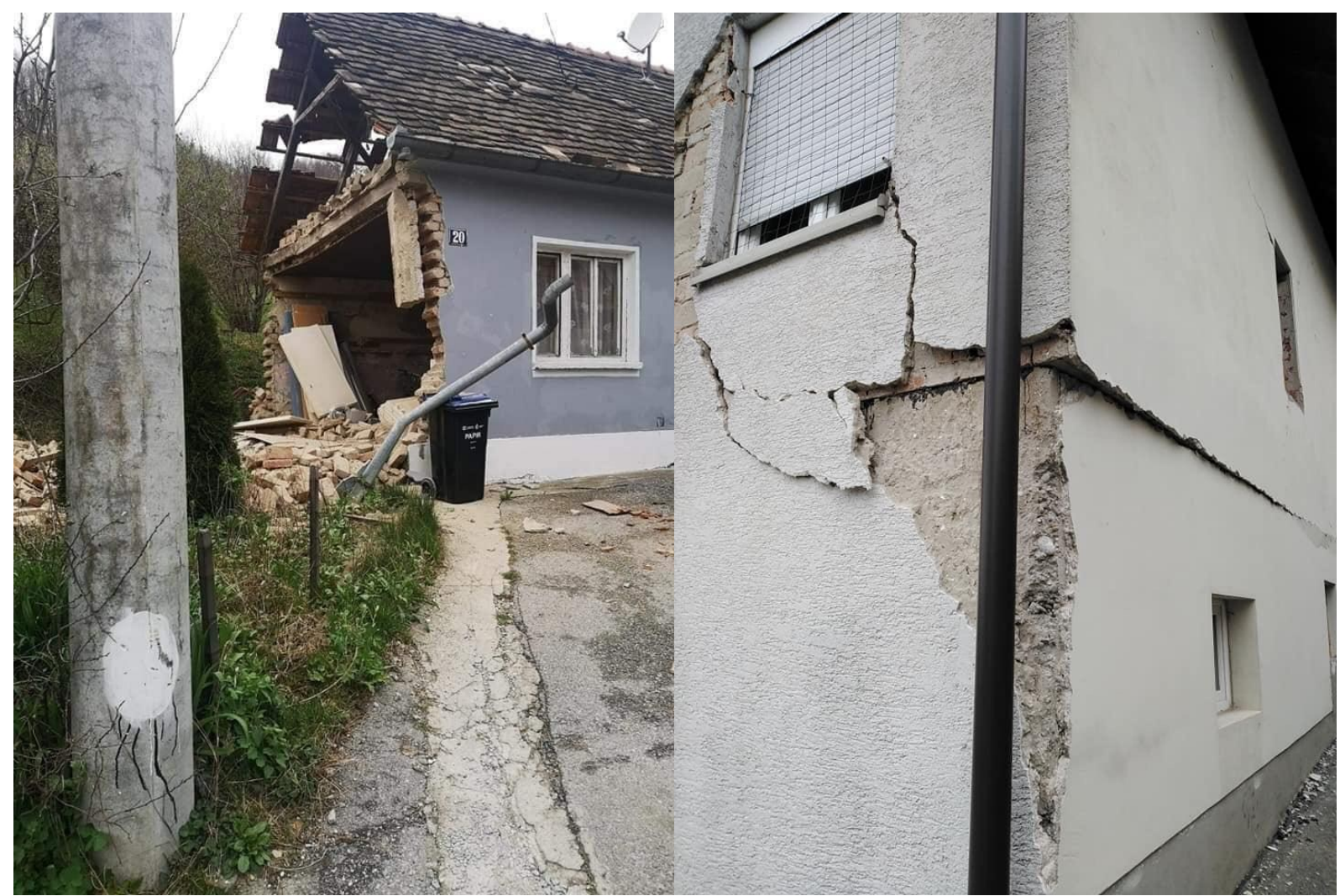

Figure 8. Heavily damaged family house near the epicenter. https://dnevnik.hr/vijesti/hrvatska/potres-u-zagrebu-ostali-bez-domova---598777.html 


\section{BACK TO THE PAST FOR THE FUTURE - HOW TO BUILD EARTHQUAKE- RESISTANT BUILDINGS}

Mohorovičić introduced concepts of seismic hazard and earthquake risk for the city of Zagreb (Mohorovičić 1909, 1911, 2009; Herak \& Herak 2009):

“...There are two sources of mistakes which would seriously endanger our buildings. The first come from ignoring the ways the earthquake affects the buildings; the other is the inadequate construction process.

Many properly executed buildings are not safe against earthquakes, simply because their foundations were made without considering the earthquake hazard. Investigating the damage on buildings from some major earthquakes during recent years, I obtained results which confirm that some general rules can be formulated. Every contractor should take these rules into account when planning the buildings, especially the very tall ones, and the buildings designed in agreement with these rules would be almost completely safe against earthquakes. One cannot speak of the absolute safety, because it is not known how strong the strongest earthquake can be, and probably it is not even possible to construct the building which would not be damaged by an exceptionally strong earthquake.

1. It is not possible to construct a building which would be safe against all possible effects of a catastrophic earthquake. If the ground beneath the building cracks, the building on it must crack too. If the ground collapses, so must the building; if the steep short waves develop on the earth's surface, the building will either crack or be destroyed.

2. By using common material a building can always be constructed which will resist all, even the strongest, earthquakes which occur in our country (up to the maximal horizontal acceleration of $2000 \mathrm{~mm} / \mathrm{s}^{2}$ ).

From the data collected in the past, one can determine the probability of strong earthquakes in Croatia and Slavonia. In the last 50 years 91 strong earthquakes occurred in our region. Of these 57 earthquakes were in the Zagreb and Varaždin counties, 20 in Primorje and 30 in the Požega county. On the mountain of Medvednica (Zagrebačka gora) there were 30 of them. It follows that in the surroundings of Mt. Medvednica, including the city of Zagreb, three strong earthquakes occur every five years.

In the last 25 years there were 3 to 4 earthquakes which induced damage, and a disastrous one in the year 1880 with great damage. In the more distant past, the earthquake of March 26th 1502 is mentioned, when the tower of St. Mark's collapsed, the other one of the year 1590 when the Medvedgrad Castle was destroyed, of 1699 when again the tower of St. Mark's was destroyed, and another one of July 1st 1756. It is hard to estimate whether these earthquakes were stronger or weaker than the 1880 earthquake. These data show that in Zagreb we have one very strong earthquake each 100 years, one weaker but damaging earthquake every 10 years, and 3 moderate earthquakes within every 5 year. It is assumed that an ordinary building has a duration of 150 to 200 years.

During its lifetime this building will have to withstand one very strong earthquake, about 100 moderate earthquakes, 100 weaker earthquakes and 1500 to 2000 very weak earthquakes, whose origin lies below the town of Zagreb or very near to it..."

If we add those earthquakes which have their foci in the greater Zagreb area, and whose shaking is also felt in Zagreb, then the numbers we obtain are very large.

It follows that the danger of earthquakes must be carefully considered when building houses in Zagreb, and that it is profitable to pay more in order to make the building as safe against the earthquake as possible.

The safer our buildings will be, the lower will be the credit interests for such buildings, and the town will grow and develop faster if the foreign guests will be free of fear of earthquakes.

The building codes for the town of Zagreb contain several rules having the purpose to secure the building from the earthquake hazards. Nevertheless, there are still many mistakes in the ways of constructing the buildings which can be avoided without increasing the costs; there are some which could be easily avoided with only slightly increased costs, taking into account also the purpose the building will serve, and the durability it was designed for.

I decided to use these lines to explain to the highly esteemed gentlemen builders and contractors about the ways how the earth is trembling and how this trembling affects the buildings, and to stress some principles which every architect and every contractor should have in mind when building our houses..."

Mohorovičić analyzed most common building elements, building types, their resistance and response to earthquake shaking (full details in Mohorovičić 1911, 2009).) and draw 15 Mohorovičić's rules how to build earthquake-resistant buildings (Table 1) that are still valid and applicable and most importantly to say, they are comparable with the basic principles of conceptual design from Eurocode-8 (2004). 
Table 1. Mohorovičić's 15 rules how to build earthquake-resistant buildings from 1911

\begin{tabular}{|c|c|c|}
\hline $\begin{array}{c}\text { Rule } \\
\#\end{array}$ & $\begin{array}{c}\text { In Croatian } \\
\text { (Mohorovičić 1911; Herak 2020) } \\
\end{array}$ & $\begin{array}{c}\text { In English } \\
(\text { Mohorovičić 2009) }\end{array}$ \\
\hline 1 & $\begin{array}{c}\text { Na strmini, a osobito na gornjem rubu strmine } \\
\text { neka se uopće ne gradi. }\end{array}$ & $\begin{array}{c}\text { On the steep slopes, especially on the upper edge of a steep } \\
\text { incline no building should be built. }\end{array}$ \\
\hline 2 & $\begin{array}{c}\text { Pomno ispitati zemljište, ako treba umjetno ga } \\
\text { pojačati. }\end{array}$ & $\begin{array}{l}\text { The soil at the site where the building is planned should be } \\
\text { carefully examined before the construction starts. If } \\
\text { necessary, the ground should be artificially reinforced. }\end{array}$ \\
\hline 3 & $\begin{array}{l}\text { Temelji zgrade neka su tako jaki i debeli, da bude } \\
\text { pritisak na zemlju po jedinice plohe, po } \\
\text { mogućnosti malen. }\end{array}$ & $\begin{array}{l}\text { The foundation of the building should be strong and thick, in } \\
\text { order to make the compression on the ground per unit of area } \\
\text { as small as possible. }\end{array}$ \\
\hline 4 & $\begin{array}{l}\text { Temelj zgrade neka je po mogućnosti monolit } \\
\text { napravaljen od betona koji se može ojačati } \\
\text { umetanjem jake željezne šipke. }\end{array}$ & $\begin{array}{l}\text { The foundation of the building should be a monolith, best } \\
\text { made of concrete (large pieces of rocks are allowed in } \\
\text { concrete). If the builder has any doubts concerning the } \\
\text { quality of the ground, he should reinforce the foundation wall } \\
\text { by inserting into it lengthwise a long and strong iron bar. }\end{array}$ \\
\hline 5 & $\begin{array}{l}\text { Ako je zgrada monolit, onda je time otpornija, čim } \\
\text { su joj stijene tanje. Kod proračunavanja debljine } \\
\text { osnovnih zidova, pregradni se mogu zanemariti. }\end{array}$ & $\begin{array}{l}\text { If the building is a monolith, and it is constructed so that it } \\
\text { can be regarded as a single hollow column, the thinner are } \\
\text { its walls, more resistant against the earthquake it will be. The } \\
\text { thickness of the walls then depends only on the load it will } \\
\text { have to bear i.e. on the weight of ceilings, roof and the other } \\
\text { loads. By calculating the thickness of the walls the weight of } \\
\text { the dividing walls need not be taken into account. }\end{array}$ \\
\hline 6 & $\begin{array}{c}\text { Radi smanjenja lateralnih deformacija valja } \\
\text { graditi krute stupove i krovove čvrsto povezane s } \\
\text { nosivim zidovima. }\end{array}$ & $\begin{array}{c}\text { In order that the building be considered a single hollow } \\
\text { column, all the walls have to be built so that any deformation } \\
\text { in the horizontal direction should be hindered as much as } \\
\text { possible. }\end{array}$ \\
\hline 7 & $\begin{array}{c}\text { Vatrobrani zid mora biti jednako čvrst ka oi svi } \\
\text { ostali zidovi i jednako čvrsto vezan sa stropovima } i \\
\text { krovom. }\end{array}$ & $\begin{array}{c}\text { Since one of the most important walls is the firewall, it has to } \\
\text { be equally solid as all the others, and equally strongly } \\
\text { connected with the ceilings and the roof. }\end{array}$ \\
\hline 8 & $\begin{array}{l}\text { Čim bude u unutrašnjosti zgrade više čvrstih } \\
\text { poprečnih zidova, tim će zgrada biti čvršća. }\end{array}$ & $\begin{array}{c}\text { More transversal strong walls the building will have, the } \\
\text { stronger it will be. }\end{array}$ \\
\hline 9 & $\begin{array}{l}\text { Sve svodove valja zamijeniti gredama jer svodovi } \\
\text { rastežu, a grede vežu zidove. }\end{array}$ & $\begin{array}{c}\text { All the arches, wherever possible, should be replaced by the } \\
\text { transversal beams, because the arches stretch the walls, and } \\
\text { the beams bind them together. }\end{array}$ \\
\hline 10 & $\begin{array}{l}\text { Smanjiti na minimum sve dijelove zgrade koji ne } \\
\text { doprinose čvrstoći (što lakša stubišta i pregradne } \\
\text { stijene, izbjegavati teške ukrase). }\end{array}$ & $\begin{array}{l}\text { All parts of the building which do not serve to increase its } \\
\text { strength should be reduced to a minimum. The stairways } \\
\text { should be as light as possible, and the same is valid for the } \\
\text { separating walls. Any unnecessary heavy ornaments } \\
\text { especially on the roof should be removed. }\end{array}$ \\
\hline 11 & $\begin{array}{c}\text { Prigradnje i krila zgrade neka se ili veoma čvrsto } \\
\text { vežu s glavnom zgradom, ili neka se grade posebne } \\
\text { neovisne zgrade. }\end{array}$ & $\begin{array}{l}\text { Attachments and wings should either be strongly connected } \\
\text { to the main building (taking care about the inner corners) or } \\
\text { should be built as separate independent buildings. }\end{array}$ \\
\hline 12 & $\begin{array}{l}\text { Svakovrsne izbočine na zgradi, ako ih već mora } \\
\text { biti, neka budu vezane s poprečnim zidovima, te po } \\
\text { mogućnosti lake i čvrste. }\end{array}$ & $\begin{array}{c}\text { Various protuberances on the building, if they are really } \\
\text { necessary, should be linked with the transversal walls and be } \\
\text { made as light and strong as possible. }\end{array}$ \\
\hline 13 & $\begin{array}{l}\text { Krov neka je lagan, čvrst i čvrsto vezan sa svim } \\
\text { zidovima. Ravni se krovovi preporučuju za } \\
\text { seizmički jako aktivna područja. }\end{array}$ & $\begin{array}{l}\text { The roof should be light, strong and, tightly connected with } \\
\text { all walls. The flat roofs are especially recommended for the } \\
\text { regions often subjected to strong earthquakes. }\end{array}$ \\
\hline 14 & $\begin{array}{c}\text { Dimnjaci neka su čim lakši i čim čvršći, čvrsto } \\
\text { vezani s krovom. }\end{array}$ & $\begin{array}{l}\text { The chimneys must be light and strong in the vertical } \\
\text { direction. Where passing through the roof, they should be } \\
\text { strongly connected with it. The height of the chimneys above } \\
\text { the roof must not exceed } 60 \mathrm{~cm} \text {. If the higher chimneys must } \\
\text { be built, their top must be tied to the roof on all four sides. }\end{array}$ \\
\hline 15 & $\begin{array}{l}\text { Da kod potresa ne pada crijep sa zgrade na ulicu, } \\
\text { neka se na rub krova metne rešetka od željeza. }\end{array}$ & $\begin{array}{l}\text { Iron railings should be mounted on the edges of the roof to } \\
\text { prevent the roof tiles from falling into the street during an } \\
\text { earthquake. }\end{array}$ \\
\hline
\end{tabular}

With respect to Figures 4 to 8 and Mohorovičić's 15 advices stated in Table 1, one can easily correlate e.g. rules 10 to 15 with building damage in Figure 5 or rules 6 to 9 with building damage in Figure 8. The cultural heritage buildings as those in Figures 4, 6 and 7, are very sensitive and require multidisciplinary approach. The obstacles in effective implementation of the earthquake risk reduction rules (such as those stated in Table 1) arise when dealing with existing built environment. The detail and degree to which building's seismic performance could be improved for expected future events, meets the technical and non-technical obstacles. The latter is related unwillingness and/or inability due to lack of initiative, lack of finances or in general the lack of proper understanding of earthquake and its consequences. The technical part i.e. knowledge on building construction 
methods and design, is increasing over the years due to significant research effort. In the case of new "starting from scratch" buildings, the potential problems of complete implementation of rules are in the obstruction of design and construction (e.g. less building material used, project modifications without authorization, nonenforcement of regulations etc.). The earthquake risk is a worldwide problem and its mitigation is related to the nature and the socio-economic character of the buildings and people.

\section{CONCLUSIONS}

If we go Back to the Past and carefully read Andrija Mohorovičić's words “After each major earthquake... possible means of prevention against the damage... immediately after an earthquake get forgotten ... another strong earthquake is needed to remind people that the building techniques should be further developed and improved..., points out that going Back to the Future after strong earthquake without looking Back to the Past, will result in exactly what we witnessed after the M5.5 Zagreb 2020 earthquake - substantial damage of cultural and historical architectural heritage of the City of Zagreb.

So unfortunately, 140 years after the Great 1880 Zagreb earthquake we were left unprepared again...

Cultural heritage, as "every material and immaterial evidence of the cultural identity of a population" is considered not only for its immediate economic value related to tourism and for its immaterial value of witness of the past, but also in a wider context as a fundamental element to maintain and promote cultural identities and differences, recognizing this as a potential instrument of progress and cooperation and as a primary component of the quality of life of citizens.

Earthquakes cause considerable damage to historical centers as we observed from the PAST Zagreb earthquakes, so that a suitable prevention policy is necessary to guarantee their conservation for the FUTURE. The first step is getting a complete knowledge of the area of interest and of the existing structures. In the selected areas, a detailed analysis to understand the characteristics of the seismic input through the analysis of seismic hazard and microzoning is needed. Also the seismic performance of buildings should be monitored in order to assess their seismic response.

Earthquakes with a very high magnitude occur relatively infrequently, most often repeatedly in certain regions in tectonically active zones. The collaboration of multidisciplinary teams (seismologists, geologists, geotechnical engineering, civil engineers, earthquake engineers, constructors, architects) is necessary. It is necessary that we work together as a multidisciplinary team: And finally, if we want that these teams work, they need strong support from the government. The social and economic cost of natural disaster like earthquake is increasing with each event. For this reason, it is important that seismic risk analysis should be made using all available information for specific earthquake event that may occur: seismic hazard, people exposure, location of the exposure related to the hazard and finally vulnerability of the people and building exposure at the hazard location. Pre-disaster event measurers and activities; prevention, mitigation, preparedness, readiness, as well post-disaster event measures and activities; response, recovery and development are all related to seismic hazard-disaster-risk circle (Milutinović \& Šalić 2004). Concepts of seismic hazard and earthquake risk for the city of Zagreb has been introduced by Andrija Mohorovičić in such a way that 111 years later, there is little one could add or improve.

\section{Let's finally listen the wisdom words of an "old man".}

\section{REFERENCES}

EN 1998-1 (2004): Eurocode 8: Design of structures for earthquake resistance - Part 1: General rules, seismic actions and rules for buildings [Authority: The European Union Per Regulation 305/2011, Directive 98/34/EC, Directive 2004/18/EC]

Herak M, Herak D (2007) Andrija Mohorovičić (1857-1936) was born 150 years ago. Newsletter - New Zealand Geophysical Society, 73, 27-29.

Herak M, Herak D (2009) Foreword to the English translation of Effects of earthquakes on buildings by A. Mohorovičić. Geofizika, 26 (1), 1-4.

Herak M (2020) ANDRIJA MOHOROVIČIĆ: Ako je u unutrašnjosti zgrade više čvrstih poprečnih zidova, zgrada će biti čvršća. Večernji list-Panorama. 8. travnja 2020. 26-27

Markušić S, Stanko D, Korbar T, Belić N, Penava N, Kordić B (2020) The Zagreb (Croatia) M5.5 earthquake on 22 March 2020. Geosciences. 252, 21. doi:10.3390/geosciences 10070252

Milutinović Z, Šalić R (2004) Planning for seismic risk reduction (S-107). Lecture notes from international twelve-week course on aseismic design and construction. CADAC 2004, October/November, Skopje.

Mohorovičić A (2009) Effects of earthquakes on buildings. Geofizika, 26, 1-65 (English translation).

Mohorovičić A (1913) Razvoj sizmologije posljednih pedeset godina, Reprinted from Ljetopis JAZU, 27, Dionička tiskara, Zagreb, pp. 31.

Mohorovičić A (1909, 1911) Djelovanje potresa na zgrade - predavanje prof. dr. Andrije Mohorovičića u H. D. I. I A. dne 1. ožujka 1909, preštampano iz »Vijesti Hrv. društva inžinira i arhitekta, Zagreb, Tiskara i litografija C. Albrechta, $79 \mathrm{pp}$. 


\section{APPENDIX: MORE FIGURES ABOUT 22 MARCH 2020 ZAGREB EARTHQUAKE}

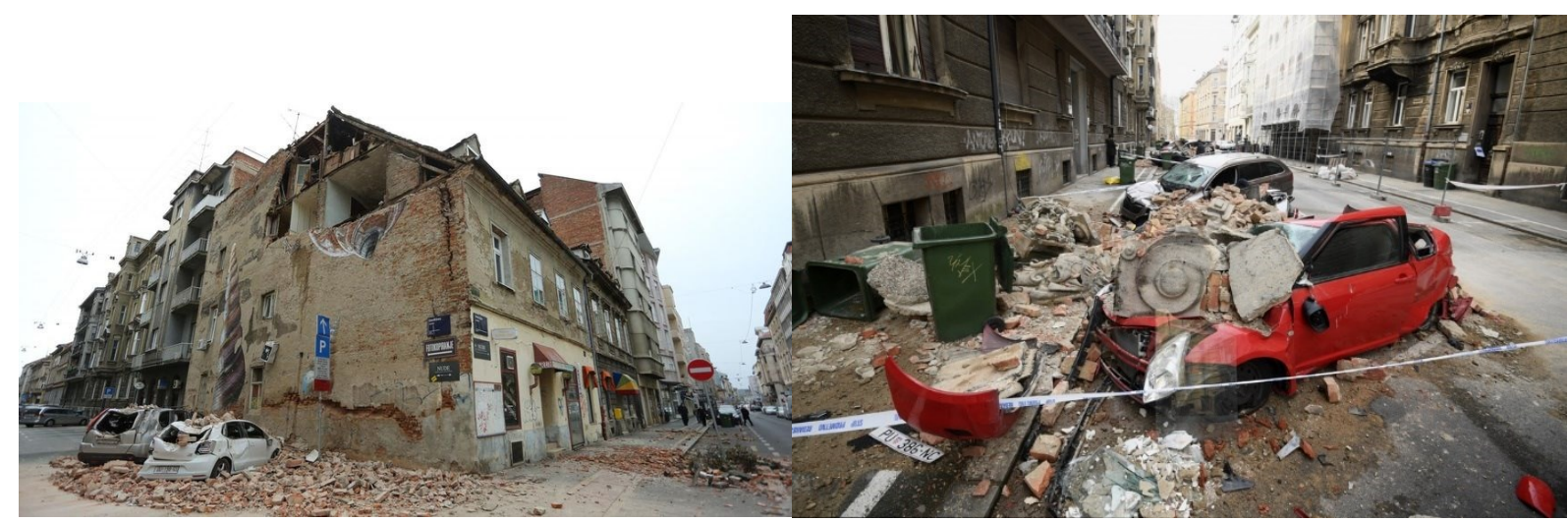

https://www.rtl.hr/vijesti-hr/novosti/hrvatska/3670825/vise-od-90-potresa-zatreslo-zagreb-steta-ce-se-sanirati-godinamaimali-smo-srece/?galerija $=2744137$

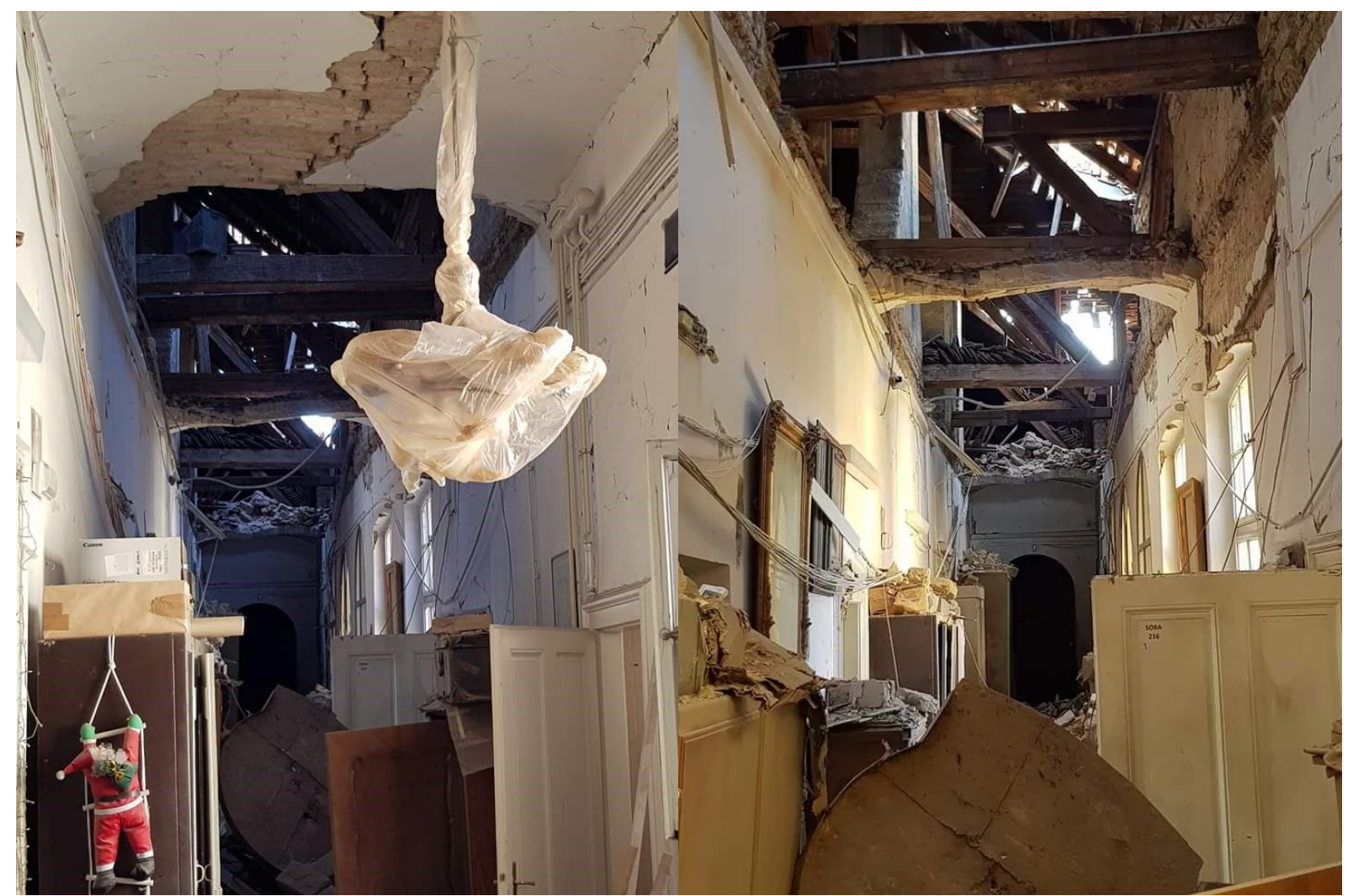

https://www.muo.hr/blog/2020/03/22/muo potres/

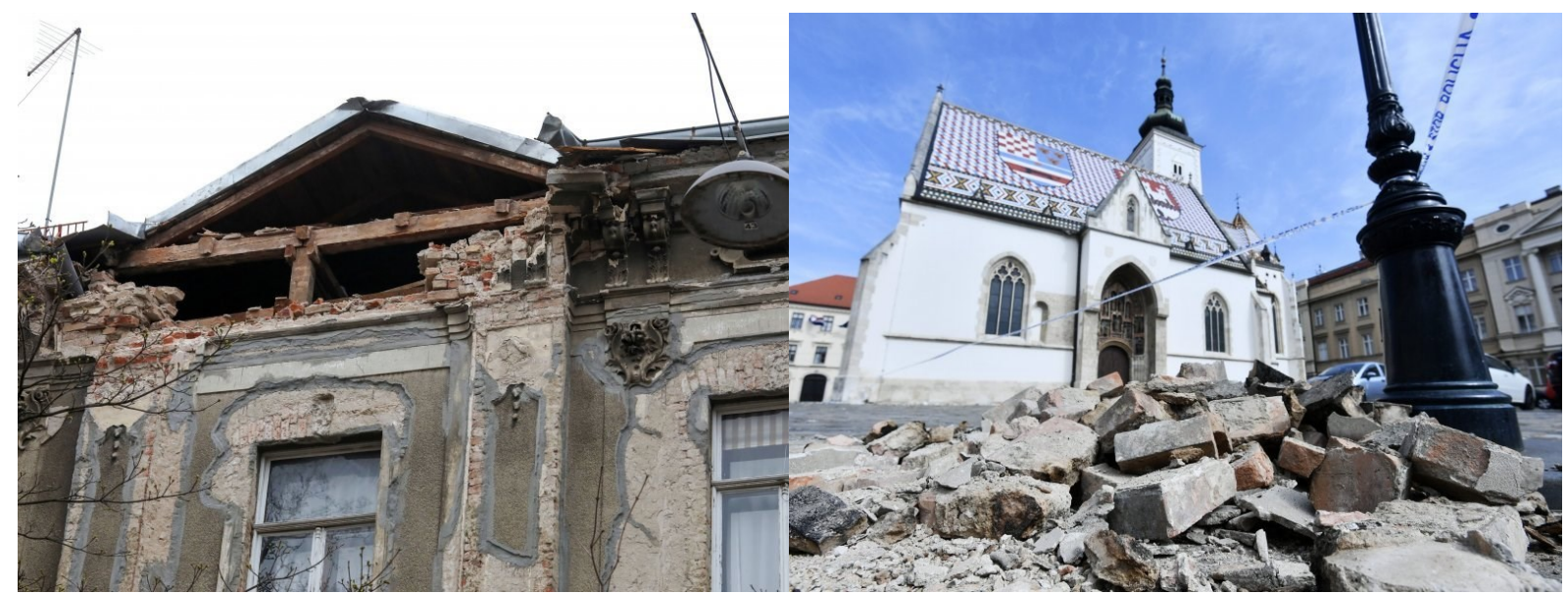

https://www.tportal.hr/vijesti/clanak/velika-fotogalerija-uvjerite-se-iz-prve-ruke-u-posljedice-razornog-potresa-koji-jepogodio-zagreb-foto-20200322 